IRA-International Journal of Education \& Multidisciplinary Studies

ISSN 2455-2526; Vol.07, Issue 03 (2017)

Pg. no. 228-234

Institute of Research Advances

http://research-advances.org/index.php/IJEMS

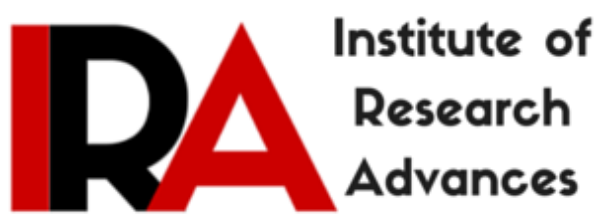

\title{
Uniformity and Diversity of Components of Teacher Education
}

\author{
Bhupendra Singh ${ }^{1}$, Dr. Patanjali Mishra ${ }^{2}$ \\ ${ }^{1}$ Research Scholar (School of Education) \\ Vardhman Mahaveer Open University, Kota (Rajasthan)-324010, India. \\ ${ }^{2}$ Assistant Professor (School of Education) \\ Vardhman Mahaveer Open University, Kota (Rajasthan) -324010, India.
}

Type of Review: Peer Reviewed.

DOI: http://dx.doi.org/10.21013/jems.v7.n3.p7

\section{How to cite this paper:}

Singh, B., \& Mishra, P. (2017). Uniformity and Diversity of Components of Teacher Education. IRA International Journal of Education and Multidisciplinary Studies (ISSN 2455-2526), 7(3), 228-234. doi:http://dx.doi.org/10.21013/jems.v7.n3.p7

(C) Institute of Research Advances.

\section{(cc) EY-NO}

This work is licensed under a Creative Commons Attribution-Non Commercial 4.0 International License subject to proper citation to the publication source of the work.

Disclaimer: The scholarly papers as reviewed and published by the Institute of Research Advances (IRA) are the views and opinions of their respective authors and are not the views or opinions of the IRA. The IRA disclaims of any harm or loss caused due to the published content to any party. 


\begin{abstract}
It was the suggestion of the National Education Commission (1964-66) that investment for teacher education can return in rich surpluses because the fiscal resources essential are small when compared to the resulting developments in the upbringing of masses. Today, it is an imperative to prepare dynamic teachers. Therefore, skill development programmes for in-service and teacher trainees should be ornamented with the teaching-learning skills, real mode internship, pedagogical knowledge with application, multi-lingual and multicultural classroom management techniques and ICT based technologies. These conditions are fulfilled by implementing the components of teacher education with uniformity in knowledge and diversity in functioning. The universal and local aspects of teacher education programs might be meaningful for the environment of training. This research article is trying to ascertain their devotion to global trends versus the impact of native circumstances and cultures. Teacher Education Curriculum-1978 very rightly emphasized on the fortune of the school curriculum which is affected by the teacher education curriculum.
\end{abstract}

Keywords: Teacher Education, Diversity, Uniformity, NCFTE (National Curriculum Framework for Teacher Education), NCF (National Curriculum Framework), NCFSE (National Curriculum Framework for School Education)

Universal phenomena frequently arise as local understanding, norms and thoughts that spread globally owing to their latent significance to other contexts. One such idea is that of social equality, which primarily was limited to a lesser part of society in an exact part of the world and was ultimately accepted by a wide range of countries throughout the world. During the age of colonization, universal ideas were spread through new relations that were made due to contamination and transition between cultures of countries. These cultural links resulted in the adoption of notions, knowledge and rules of behaviour. Nowadays, technology is connecting the world through more reasonable opportunities, general artistic references (through movies and Television shows) and the internet which provide direct communication.

Today, technology is allowing for a quick spread of cultural wealth including features that reflect, as well as shape societies and humanities, such as etymological, style, talent and even nutrition. Teacher education programs compose a principal component of schooling, conveying educational ideologies and models of teaching. (Steiner, 1996) opines that advances in the process of universalization have controlled educators to consider the potential roles of the universal teacher. According to (Steiner, 1996), the critical role of the comprehensive teacher is, however, another indicator of the impact of research on teacher education in the common and native context.

(Darling-Hammond et al., 2005) concluded that another global ideal of teacher education is finding the balance between theory and practice, providing student teachers with the necessary theoretical background as well as the practical knowledge needed to prepare future teachers for the challenges of teaching. (Wildavsk, 2010) wrote in his work The Great Brain Race that "The globalization of higher education should be embraced not feared by the worldwide competition for human talent, the race to produce innovative researchers, the extension of university campuses and the rush to produce knowledgebased economies. All of these trends are hugely beneficial to the entire world".

(Korthagenet al., 2006) stated that outdated methods of teacher education are increasingly criticized for their limited relationship to student-teacher, needs and their little control on training. Many pleas are heard for an essentially new and operative pedagogy of teacher education in which theory and practice are interrelated efficiently. 


\section{Theoretical and Practical Framework}

An example of a universal principle and its adaptation to indigenous contexts concerns the role of schools in teacher education. NCF-2005 (National Curriculum Framework) provides basic knowledge for teacher education about the pedagogy of teaching and learning, development of a child, learning motives and assessment of learning and NCFTE-2009 (National Curriculum Framework for Teacher Education) emphasizes on internship for teacher trainees, objectives of teaching, innovation in Information and Communication Technology, and constructive ideas. The theoretical and practical framework of teacher education in India has evolved by recommendations of National Education Commission (1964-66), NPE1986, and Programme of Action (PoA) 1992, Acharya Ramamurthy Committee (1990), Yashpal Committee (1993), NCF (2005) and NCFTE (2009). Within the centralized arrangement of the India broad policy and legal framework on teacher education is provided by the Central Government and implementation of various policies, programmes and orders are assumed largely by state governments. In the interior the comprehensive objectives of improving the learning attainments of learner, two identical strategies are to-

1. Prepare teachers for the school system (pre-service teacher trainees) and

2. Improve capability of surviving school teachers (in-service teachers).

For pre-service teachers' training, the National Council for Teacher Education (NCTE), a legal body established by the Central Government, is responsible for planning, coordinating and developing of teacher education in India. The NCTE sets up different norms and criteria for various teacher education courses, qualifications for teacher educators and teacher trainees, content and duration of the different courses. It also provides recognition to institutions (government, aided and self-financed) interested for running such type of courses (D.Ed., D.El.Ed., B.El.Ed., B.Ed. or M.Ed.) of teacher education.

For in-service teachers' training, In India, a vast network of government-owned teacher training institutions is available, which provides straining for in-service teachers. At the National Level, National Council of Educational Research and Training (NCERT) with its six Regional Institutes of Education is continuously preparing modules for different teacher training courses and also undertaking specific programmes for training of teachers and teacher mentors. Official care is also providing by (National University of Educational Planning and Administration) NUEPA (previously NIEPA). Both NCERT and NUEPA are autonomous bodies at national level. At the state level, SCERTs (State Councils of Educational Research and Training which is previously known as SIERTs) are preparing units for teacher education courses and conducting special courses for teacher mentors, school teachers as well as for trainers. Institutes of Advanced Learning in Education (IASEs) and Colleges of Teacher Education (CTEs) are developing skills of in-service teachers' of secondary and senior secondary school as well as of teacher educators. Others as (District Institutes of Education and Training) DIETs at the district level, (Block Resource Centres) BRCs at the block level and (Cluster Resource Centres) CRCs at cluster level are providing training for in-service teachers with their perfection.

\section{Teacher Education and Human Rights}

Human rights are deep-seated in the Indian Constitution and are as primordial as human civilization. All civilizations and cultures have in the past settled some idea of rights and codes that should be respected and have been considered collective in nature. Particularly, the idea of Vasudhaiv Kutumbakam contains the essence of human rights in Indian civilization. The Rig Veda, the oldest document declares that all people are equal. The Atharva Veda favours equal rights over all natural resources. Before independence, the struggle for rights was started by Mahatma Gandhi with the national freedom movement for self-governance and independence as the birthright of the people which is known as Swaraj. Thus, Indian philosophy and social tenet provided a complete moral base for rights. Mahatma Gandhi's contribution to rights cannot be forgotten. 
Mahatma Gandhi, the promoter of peace and advocate for non-violence, wrote a letter to Dr. Julian Huxley, Director General of (UNESCO, 1948), on May 25, 1947, which has great relevance today. In this letter, Mahatma Gandhi wrote "I learnt from my illiterate but wise mother that all rights to be deserved and preserved came from duty well done. Thus the very right to live accrues to us only when we do the duty of citizenship of the world. From this one fundamental statement, perhaps it is easy enough to define duties of man and woman and co-relate every right to some corresponding duty to be first performed". (Introduction by Jacques Maritain)

Today RTI (Right to Information), RTE (Right to Equality), RTE (Right to Education), RTL (Right to Life), Right to Social Security, Right to Participate in the Cultural Life of Community, etc. are given by the Constitution of India, studying in schools and teacher education institutions to aware the rights of individuals.

\section{Universal ideas for shaping teacher education programmes}

Professionalism is an important ideal situation that supplements many educational programmes as well policies making of education and teacher education. Today, the ideas of professionalism are shared by many teacher education organizations. Teacher education is not merely related to non-technical educators but also technical educators. (Bransford et al., 2005) in his book Preparing Teachers for a Changing World: What teachers should learn and be able to do wrote that "The quest that we are undertaking is similar to ones previously pursued in other professions... fields like engineering, law, and architecture also worked to develop a consensus about professional education later in the twentieth century. As they did so, they considered what core content students should encounter and what intellectual capacities and disposition they should develop in order to think like a lawyer or an engineer or a doctor and to meet the needs of their clients."

In favour of teacher education (Simola et al., 1997) described that "U.S. Reports The Nation Prepared and Tomorrow's Teacher of 1986 have been especially important for constructing the practically undisputed opinion that teaching should be regarded more as standard professional work, like that of the medical surgeon." (Darling-Hammond, 2006) stated that "teaching is a profession with certain moral and technical expectations especially the expectation that teachers, working collaboratively, will acquire, use, and continue to develop shared knowledge on behalf of students."

Professionalism motivated the academisation of teacher education programmes. For example, in most nations studies are leading to teacher certificate with the grant of academic degrees like D.Ed., D.El.Ed., B.El.Ed., B.Ed. or M.Ed. etc. (Korthagen et al., 2006) believed that "Traditional approaches to teacher education are increasingly critiqued for their limited relationship to student teachers' needs and for their meager impact on practice. Many pleas are heard for a radical new and effective pedagogy of teacher education in which theory and practices are linked effectively." Today role of a teacher educator is-

1. to aware student-teachers for diverse school populations,

2. to provide necessary tools to improve skills,

3. to prepare them for multicultural and multi-lingual classrooms and,

4. to prepare for the vastly changing world.

(Causey et al., 2000) opine that "while student populations grow more diverse, the pre-service teacher population is becoming more homogeneous, primarily white and middle-class. One challenge for teacher preparation programs arising from the mismatch of teacher and student cultures is to facilitate intercultural sensitivity and learning among prospective teachers." 


\section{Coactive Connections between School Education Curriculum and Teacher Education Curriculum}

There is a coactive relationship between school education curriculum and teacher education curriculum. Therefore it is essential to have a brief discussion on school education curriculum from the perspective of human rights education. The curriculum frameworks for school education-1975, 1988 and 2000 disclose that human rights education has been adjoined into the school curriculum in several ways as formal, informal, non-formal and hidden curriculums.

The teacher education curriculum in India has been regularly revised in 1978, 1988, 1998 and 2009 with the gap of every 10 years to return and unite the linguistic, cultural and geographical diversities of our country and retaining pace with the shifting knowledge structure of the world as the result of social, cultural, political, economic disturbances and, scientific and communication innovations.

The National Curriculum Framework for School Education (NCFSE-2000) envisions the teacher education program as one of the most real and comprehensive tool of quality enhancement in school education. The curriculum development involves attentions about curriculum applicability. Thus it is compulsory that the curriculum should detect the requirements of the learners and teacher trainees with professional practice. The requirements of applicability of school education curriculum and teacher education curriculum are not fixed. Because of the view of both is consistent with the dynamic and situational approach. The basic categories which define curriculum progress are curricular activities, theory practice, innovative learning and constructive teaching and learning. The exercise of the task-based curriculum with the focus of adaptable skills is the ideal demand of education. (NCFSE, 2000) discloses that "Perspectives of teacher education emerge from the objective of school education, which reflects concerns for the fulfillment of individual's potential in harmony with collective human aspirations." Therefore, teacher educators, in-service teachers and teacher trainees shall have to invest themselves with an exhaustive understanding of education so that they can communicate the correct principle of education.

The (UNESCO, 1974)'s recommendation concerning "Education for International Understanding, Cooperation and Peace and Education relating to Human Rights and Fundamental Freedoms "reflected its possibility and the comprehensive choice of tasks of teacher education institutions. The Recommendation also talked the necessity for in-service education for managers and other school employees.

\section{NCFTE-2009: Its Uniformity and Diversity}

National Curriculum Framework for Teacher Education was prepared by the National Council for Teacher Education (NCTE) and was disseminated in March 2009. This framework for teacher education has been prepared in the light ground of the NCF (2005) and the principles laid down in the Right of Children to Free and Compulsory Education Act-2009 which demanded an altered framework on teacher education with the changed philosophy of school curriculum. While enunciating the vision of teacher education, the framework for teacher education has some significant extents of the new approaches to teacher education as-

1. Insightful rehearsal to be the principal aim of teacher education.

2. Providing opportunities for self-learning, reflective learning, adjustment and articulation of new ideas to the pupil-teachers.

3. Developing abilities for self-directed learning and ability to reflect, criticism.

4. Providing opportunities to observe and engage with children.

5. Develop skills to communicate and connect with children.

The NCFTE-2009 has highlighted the focus, objectives, different aspects of theoretical and practical learning, and assessment approaches for the various initial teacher education programmes. The framework also outlines the elementary issues of courses of teacher education. NCFTE-2009 has made several recommendations on the tactic and practice of in-service teacher training programmes. As a usual 
outcome to the NCFTE-2009, the NCTE has developed model syllabuses for various teacher education courses like D.Ed., B.Ed. and M.Ed. etc.

\section{Conclusion}

It is well known that the appearance of universal motifs is varied according to local circumstances, opinions and cultures. The worldwide teacher education programmes also have some restrictions with the local opinions, cultural diversities and socio-political barriers, etc. According to (Tamir, 2010) "The strength of this type of teacher preparation lies in its ability to recruit and engage new teachers in a coherent mission and a set of values, ideas and beliefs concerning teaching, society and religion that the program promotes." Today teacher education plays the most significant role in the development of a country. Teacher education consists of the organization, personnel and its standards. Therefore, it is essential to be inter-related, uniform and diverse of components of teacher education. Comprehensive thoughts might spread through-

1. Diverse communication implements between professional communities and governments.

2. Publications of literature.

3. The web or non-web media.

\section{References}

[1]. Arora, G.L. and Panda, Pranati (2000). Fifty Years of Teacher Education in India: Post Independence Developments, New Delhi: NCERT.

[2]. Bransford, J., Darling-Hammond, L. \& LePage, P. (2005). Introduction. In: DarlingHammond, L. \& Bransford, J. (Eds.), Preparing Teaching for a Changing World: What teachers should learn and be able to do. San Francisco: Jossey-Bass. pp. 1-39

[3]. Causey, V. E., Thomas, C. D. \& Armento, B. J. (2000). Cultural diversity is basically a foreign term to me: the challenges of diversity for preservice teacher education. Teaching and Teacher Education, 16, pp. 33-45.

[4]. Darling-Hammond, L. (2006). Constructing 21st-Century Teacher Education. Journal of Teacher Education, 57, pp.1-15.

[5]. Darling-Hammond, L., Hammerness, K., Grossman, P., Rust, F. \& Shulman, L. (2005). The Design of Teacher Education Programs. In: Darling-Hammond, L. \& Bransford, J. (Eds.), Preparing Teaching for a Changing World: What teachers should learn and be able to do. San Francisco: Jossey-Bass. pp. 390-441

[6]. Korthagen, F., Loughran, J., \& Russell, T. (2006). Developing fundamental principles for teacher education programs and practices. Teaching and Teacher Education, 22, pp. 10201041.

[7]. NCERT (2005). NCF 2005. New Delhi: NCERT.

[8]. NCTE (2009). National Curriculum Framework for Teacher Education: Towards Preparing Professional and Humane Teacher. New Delhi: National Council for Teacher Education.

[9]. Pandey, Saroj (2007). Professionalization of teacher education in India: A critique of Teacher Education Curriculum reforms and its effectiveness. New Delhi: Department of Teacher Education and Extension (NCERT).

[10]. Paths to peace: India's voices in UNESCO: 64 years of UNESCO-India co-operation. (2009). New Delhi: UNESCO.

[11]. Simola, H., Kivinen. O. \&Rinne, R. (1997). Didactic closure: Professionalization and Pedagogic Knowledge in Finnish Teacher Education. Teaching and Teacher Education, 13(8), pp. 877-891.

[12]. Steiner, M. (1996). Developing the global teacher: theory and practice in initial teacher education. Stoke-on-Trent: Trentham Books in association with World Studies Trust. 
[13]. Tamir, E. (2010). The retention question in context-specific teacher education: Do beginning teachers and their program leaders see teachers' future career eye to eye. Teaching and Teacher Education, 26, pp. 665-678.

[14]. UNESCO (1948). Human Rights: Comments and Interpretations, Introduction Jacques Maritain, New York: Columbia University Press. p.18.

[15]. UNESCO (1974, November 19). Recommendation concerning Education for International Understanding, Co-operation and Peace and Education relating to Human Rights and Fundamental Freedoms. Retrieved December 14, 2016, from http://portal.unesco.org/en/ev.php-url_id=13088\&url_do=do_topic\&url_section=201.html

[16]. Wildavsky, B. (2010). The great brain race: how global universities are reshaping the world. Princeton: Princeton University Press.

[17]. GOI (1964). Report of the Education Commission 1964-66 (Vol. 2). New Delhi: NCERT. pp. 319-396

\section{Author (s) Profile}

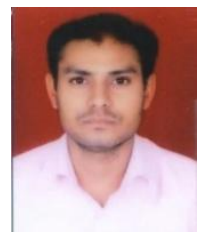

Mr. Bhupendra Singh is a research scholar and currently pursuing research in the area of curriculum designing at Vardhman Mahaveer Open University, Kota Rajasthan.

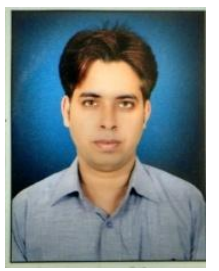

Dr. Patanjali Mishra is currently working as an Assistant Professor in Vardhman Mahaveer Open University, Kota Rajasthan. His area of interest lies in the field of Quality Management of Education, Teacher Education and curriculum designing. He has published dozens of research papers in various reputed Journals of Education. 